\title{
Reinventing Northeastern Religious Tourism in Brazil during the COVID-19 Pandemic
}

\author{
Christian Dennys Monteiro De Oliveira1, Maria Lúcia Bastos Alves², Josenildo Campos Brussio³, \\ Ricardo Lanzarini'2, Silvana Pirillo Ramos ${ }^{4}$, Amanda Priscila Souza E. Silva², \\ Ana Angélica Fonseca Costa5, Itamara Freires Menezes², Elidomar Alcanforado6, \\ Ivo Luís Oliveira Silva7 , Jânio Roque Barros de Castro ${ }^{8}$, Kaíse Canuto Da Silva99, \\ Luís Américo Silva Bonfim ${ }^{10}$, Maristela Andrade11, Renata Mayara Moreira De Lima4, \\ Rosalma Diniz Araújo 11
}

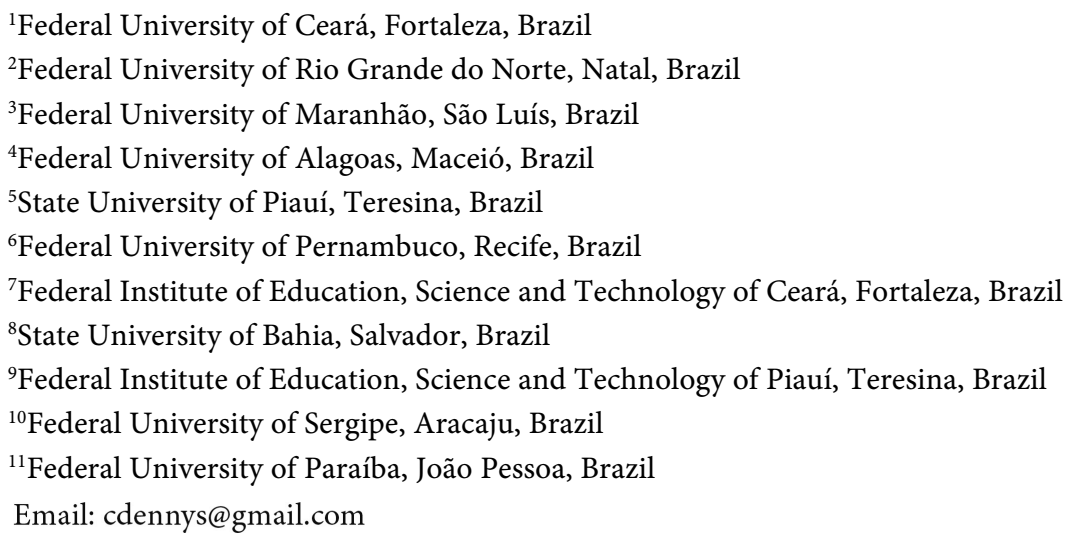

How to cite this paper: De Oliveira, C. D. M., Alves, M. L. B., Brussio, J. C., Lanzarini, R., Ramos, S. P., Silva, A. P. S. E., Costa, A. A. F., Menezes, I. F., Alcanforado, E., Silva, I. L. O., de Castro, J. R. B., Da Silva, K. C., Bonfim, L. A. S., Andrade, M., De Lima, R. M. M., \& Araújo, R. D. (2021). Reinventing Northeastern Religious Tourism in Brazil during the COVID-19 Pandemic. Open Journal of Social Sciences, 9, 92-117. https://doi.org/10.4236/jss.2021.97007

Received: May 28, 2021 Accepted: July 13, 2021 Published: July 16, 2021

\begin{abstract}
The current national and international scenario has specific characteristics stemming from the COVID-19 pandemic that spread throughout the planet in early 2020, motivating a series of political, social, environmental, economic and cultural discussions regarding different institutions, religious practices and social actors. In the context of social and physical distancing, decreed by the World Health Organization (WHO) and made flexible in some countries, such as Brazil, the adaptations made to reduce religious displacement significantly impacted social, economic and cultural activities in both small pilgrimage sites and large centers of national devotion. The present paper aims to problematize and describe Catholic religious celebrations present in the nine (9) Brazilian northeastern states during the pandemic. It follows a qualitative approach with digitally collected data, which brings to light perceptions and concerns that are instrumental in building an overview of religious tourism. As a result, it presents three dimensions that point to challenges for the reinvention of re-
\end{abstract}


Copyright $\odot 2021$ by author(s) and Scientific Research Publishing Inc. This work is licensed under the Creative Commons Attribution International License (CC BY 4.0).

http://creativecommons.org/licenses/by/4.0/ gional religious tourism, hierarchizing the predominance of devotional resistance over technological bets and possible partnerships with other sectors of local public life.

\section{Keywords}

Religious Tourism, Brazilian Northeast, Pandemic, Catholicism, Adaptations

\section{Introduction: Challenges}

From March 2020 to February 2021, various political, administrative and academic spheres have assessed the socio-environmental impact of the global catastrophe caused by the COVID-19 (SARS-Cov-2) pandemic. It is the operationalization of scientific data and information, in the most different fields of knowledge (especially Public Health), in an accelerated search for mitigation of the social and economic damages caused by a new, highly contagious and lethal disease.

Besides the serious social and economic impact, the consequences of which are still far from being measured, there arises the exponential perspective of the use of cyberspace and communication, allowing a structural reformulation of the forms of daily coexistence, either in public and private institutions, or in the personal and social response to this and other diseases. Cyberspace and the COVID-19 pandemic have redesigned-and continue to design, even with the start of the vaccination campaign - two impactful ways of making the long quarantine of contemporary social distancing feasible, which give rise to new forms of social relationship. Such cyberspace, as Levy (1999: p. 92) puts it, is capable of simultaneously decoding and converging organizational structures into informational rhizomes. Ecclesiastical institutions, private organizations and devotees-thus connected by means of various digital platforms-redefine the parts they take in religious celebrations; by allowing immediate accessibility of information and services, events enhance their local, regional and global interactions, allowing the exchange of ideas, products and services, which, in their turn, foster religious culture, and consequently tourism.

Such an anomalous context paradoxically shrinks and expands research alternatives. Attentive to the prospect of building research and service collaborative networks, religious tourism study groups in the Brazilian Northeast joined to form REPETUR-NE ${ }^{1}$. REPETUR-NE allowed for systematic observation of the pandemic panorama and the use of cybernetic devotional survival strategies in several

${ }^{1}$ The Brazilian Northeast Religious Tourism Network (REPETUR) was born in June 2020, under the organization and coordination of Maria Lúcia Bastos Alves, PhD, due to Notice No. 1/2020, which fosters research networks, issued by the Federal University of Rio Grande do Norte Reserch Vice-Rectorate (PROPESQ/UFRN) The network arises from the desire to elaborate content for reflection on the serious ongoing crisis, aggravated by the COVID-19 pandemic, which brought about intersectional debates between various social spheres, with the main objective of analyzing how responses to the coronavirus pandemic impacted pilgrimages sites that double as tourism centers. 
northeastern visitation centers. The year 2021 started with such an integration of viewpoints challenging us to consolidate a first overview of the reinvention of religious tourism, in face of the many adversities witnessed: events suspended, services, celebrations and liturgies rescheduled, pilgrimages and processions canceled or redirected, as well as a high instrumentalization of broadcasts (recorded or online) of the main program of religious festivals. These exemplify the emergency exits followed so that dates and celebrations are not forgotten, not only fostering faith, but also tourism and the desire of travel as a sociability practice for faith-driven pilgrims, tourists and residents seeking leisure and entertainment.

The present study aims to present a preliminary and approximate overview of these adaptations in religious practice, which are seriously affecting tourist visitation, and pastoral and administrative organization of the receiving centers. REPETUR's team gathered a series of instructions, adaptations and reactions from religious activities' agents/organizers, selectively collecting changes observed in certain celebrations' latest editions. The intention is to demonstrate, however partially, that there has already been room for a more syncretic reception of hybrid face-to-face/virtual actions, given of the impediments that have restricted supply and demand of Brazilian northeastern religious tourism.

\section{Materials and Methods}

The methodological choice for distance (or online) observation translates a systematic effort to overcome the research limitations ensuing from suspension or cancellation of on-site empirical research. There is little discussion on how and when qualitative research should be undertaken. The specific question of the present study is: what level of adaptation is northeastern religious tourism showing, given the pandemic and the possibility of virtual broadcast? To think about our own research, we have welcomed to the sensitivity of Vera Lúcia Santos and Cleide Costa (Federal University of Alagoas), as they have set the conditions for the study of online discussion forums, and stated the need for methodological tools, such as: questionnaires, interviews, focus groups, netnography, and observation (Santos \& Costa, 2015: p. 59). The mediation of reality by electronic and, more recently, real-time digital devices relates to the current transformations in the field of religious experience (Carranza, Carvalho, \& Bandeira, 2020) and of religious tourism (Senghor, 2020).

As Boni (2020) states, the web represents an important research tool to obtain primary data, and has been used since the 1990s by different fields of knowledge that discuss its possible shortcomings and the need for methodological improvements. In times of COVID-19 pandemic, web research is established as the main source of primary and secondary data for understanding reality.

As festivities in honor of patron saints approach, religious, political and economic entities spring into action, by means of information websites, photo archives, guides, and social and religious schedules detailing how celebrations are to 
take place. In general, these festivities encompass a "ritual complex" of processions, liturgical ceremonies, motorcades, horseback rides, vow-keeping, among other acts of faith expressing joy, emotion, pain, faith and hope. In the websites consulted, it was possible to see the emotion-laden messages of interacting users, and various narratives, from those posted by parishes and endorsed by congregation members and social agents to advertisements by local companies and public institutions. In cyberspace, cultural, religious and political identities undergo a continuous process of transformation, gravitating between the lasting and the ephemeral, which in a way entails uncertainty, anguish and destabilization (Hall, 2006). This reality allows different temporalities to occupy the same space, concomitantly experienced in a kind of redefinition and readaptation of the celebrations, or, as Canclini (2006: p. 28) puts it, a constant exchange between modern, archaic, erudite, popular or massive that generates cultural hybridizations.

In this search for ways to reinvent devotional experiences and religious tourism in the Northeast, the need for the exploratory collection of reports and interviews and for discussion on how to best "celebrate without agglomerate" has become a game of trial and error. There has been much discussion on the possibility of renewing tourism project, in a game of polarities, a plot of local/regional interests. Some authors are critical of tourism as an exaggerated reinvention of traditions, especially within the perspective of Hobsbawm and Ranger (eds., 1997) in the cultural field of religion. Other more creative researchers have given "reinvention" a much more technical-operational (Palhares, 2015) or imagetic and market-based (Sánchez, 2003) status. Given the reinvention of tourism itself, the current scenario appears less rigid, as challenges are qualitative and exploratory, without reference to other devotional events that may have existed in the history of the northeastern localities here under study, thus reinventing a solution to the problem of the pandemic and social distancing by means of ICT. The reinvention here is a continuous experimentation on the current difficulties and resistance to deal with significantly altered feasts in the last 12 months, as well as on our fieldwork procedures and the understanding of religious experience in tourist events on cyberspace (Camargo, Santos, \& Guterres, 2012).

This methodological option took into account a virtual environment marked by an ambivalent religiosity once seen as oppositional pairs, modern/traditional, official/popular and coastal/backland, and now regarded as interchangeable and juxtaposed present in the most varied circumstances.

The methodological procedures and steps adopted are not equivalent, precisely because data collection occurs in such adverse conditions; nor was it possible to standardize a data sequence within a year brimming with observation (March, 2020 to February, 2021). After all, there was neither time nor means to remodel celebrations scheduled for the first half of 2020 in a way similar to those of the second half onwards. Something similar has happened with the organization of the research teams in their access to the organizers and participants of these celebrations. The field did not update itself; at the same time, refashioned its 
channels of observation and information into a kind of e-field, that is, remote empirical access, within its means and limitations. This was as unusual as challenging, and open to the overview of locations exposed below, albeit briefly. Table 1 summarizes the events and localities under study in the nine states that make up the geographical region of the Brazilian Northeast: 1) Alagoas (AL, capital city: Maceió), 2) Bahia (BA: capital city Salvador), 3) Ceará (CE: capital city Fortaleza), 4) Maranhão (MA capital city São Luís), 5) Paraíba (PB, capital

Table 1. Overview of Brazilian northeastern religious tourism adaptations in certain places and events.

\begin{tabular}{|c|c|c|c|}
\hline States & Cities & Events & Dates \\
\hline $\mathrm{AL}$ & Penedo & $\begin{array}{c}\text { Festa de Bom Jesus dos Navegantes } \\
\text { [Feast of Our Good } \\
\text { Lord Jesus of the Seafaring] }\end{array}$ & $\begin{array}{c}\text { January } \\
7-10,2021\end{array}$ \\
\hline BA & Candeias & $\begin{array}{l}\text { Festa de Nossa Senhora das Candeias } \\
\text { [Feast of Our Lady of Candeias] }\end{array}$ & $\begin{array}{c}\text { March, } \\
2020\end{array}$ \\
\hline \multirow{2}{*}{$\mathrm{CE}$} & Canindé & $\begin{array}{l}\text { Feasts of the Sanctuary of } \\
\text { St Francis of the Wounds }\end{array}$ & $\begin{array}{l}\text { July, September, } \\
\text { November, } 2020\end{array}$ \\
\hline & Juazeiro do Norte & $\begin{array}{c}\text { Feasts of the Juazeiro } \\
\text { do Norte Sanctuary }\end{array}$ & $\begin{array}{l}\text { February, } \\
2021\end{array}$ \\
\hline MA & $\begin{array}{l}\text { Sanctuary of St Joseph } \\
\text { of Ribamar, } \\
\text { São José do Ribamar }\end{array}$ & $\begin{array}{l}\text { Festejo de São José do Ribamar } \\
\text { [Feast of St Joseph of Ribamar] }\end{array}$ & $\begin{array}{l}\text { September, } \\
2020\end{array}$ \\
\hline $\mathrm{PB}$ & $\begin{array}{l}\text { Sanctuary of Our Lady } \\
\text { of Penha, João Pessoa }\end{array}$ & $\begin{array}{l}\text { Romaria da Penha } \\
\text { [Penha Pilgrimage] }\end{array}$ & $\begin{array}{l}\text { November, } \\
2020\end{array}$ \\
\hline \multirow{3}{*}{$\mathrm{PE}$} & Brejo da Madre de Deus & $\begin{array}{c}\text { Paixão de Cristo de Nova Jerusalém } \\
\text { [Passion of our Lord Jesus } \\
\text { Christ of New Jerusalem] }\end{array}$ & $\begin{array}{l}\text { Holy Week, } \\
2020\end{array}$ \\
\hline & $\begin{array}{l}\text { São Joaquim } \\
\text { do Monte }\end{array}$ & $\begin{array}{l}\text { Romaria de Frei Damião } \\
\text { [Pilgrimage of Friar Damian] }\end{array}$ & $\begin{array}{c}\text { September } \\
3-6,2020\end{array}$ \\
\hline & Serrita & $\begin{array}{l}\text { Missa do Vaqueiro } \\
\text { [Cowherd Mass] }\end{array}$ & $\begin{array}{l}\text { Holy Week, } \\
2020\end{array}$ \\
\hline \multirow{4}{*}{ PI } & & $\begin{array}{c}\text { Festa da Invenção da Santa Cruz } \\
\text { [Feast of the Invention of the Holy Cross] }\end{array}$ & $\begin{array}{l}\text { May, } \\
2020\end{array}$ \\
\hline & $\begin{array}{l}\text { Santa Cruz } \\
\text { dos Milagres }\end{array}$ & $\begin{array}{c}\text { Exaltação da Santa Cruz } \\
\text { [Exaltation of the Holy Cross] }\end{array}$ & $\begin{array}{l}\text { September, } \\
2020\end{array}$ \\
\hline & & $\begin{array}{c}\text { Encontro dos Santos } \\
\text { [Encounter of the Saint] }\end{array}$ & $\begin{array}{l}\text { November, } \\
2020\end{array}$ \\
\hline & Oeiras & $\begin{array}{l}\text { Festa do Bom Jesus dos Passos } \\
\text { [Feast of Our Good Lord } \\
\text { Jesus of the Steps of the Cross] }\end{array}$ & $\begin{array}{l}\text { Holy } \\
\text { Week }\end{array}$ \\
\hline \multirow{2}{*}{ RN } & $\begin{array}{l}\text { Sanctuary of St Rita } \\
\text { of Cascia, Santa Cruz }\end{array}$ & $\begin{array}{l}\text { Festa de Santa Rita de Cássia } \\
\text { [Feast of St Rita of Cascia] }\end{array}$ & $\begin{array}{c}\text { May 22, } \\
2020\end{array}$ \\
\hline & Caicó & $\begin{array}{l}\text { Festa de Sant'Ana } \\
\text { [Feast of St Anne] }\end{array}$ & $\begin{array}{c}\text { July 26- } \\
\text { August 2, } 2020\end{array}$ \\
\hline SE & São Cristóvão & $\begin{array}{l}\text { Festa de Nosso Senhor dos Passos } \\
\text { [Feast of Our Good Lord Jesus } \\
\text { of the Steps of the Cross] }\end{array}$ & $\begin{array}{l}\text { March 6-8, } \\
2021\end{array}$ \\
\hline
\end{tabular}


city João Pessoa), 6) Pernambuco (PE, capital city Recife), 7) Piauí (PI, capital city Teresina), 8) Rio Grande do Norte (RN, capital city Natal) and 9) Sergipe (SE, capital city Aracaju).

\section{The Different Scenarios in Northeastern Religious Events}

Celebration and visitation centers do not follow a pre-established order in terms of density or time, nor do they yield criteria with which to measure quarantine-induced changes. The following record is an overview, oscillating among types of survey, according to the situation, whether observation was done exclusively online or associated with technical visits and interviews portraying the latest editions of events.

The presence of mass media channels has altered traditional forms of participation in the celebrations of the Christian calendar, as digital technologies enable access to the time of the festivities. By means of virtual interaction, believers become generators and propagators of beliefs, by their testimonies and posts, keeping alive the "flame of faith".

Following technological evolution and the ensuing cultural and social changes, the Catholic Church has gradually invested on ICT: websites, blogs, YouTube channels, Instagram profiles, etc. that enable new forms of devotion, participation and interaction with the sacred.

Discussing religiosity in social networks and media during the pandemic, Renata Menezes (Menezes et al., 2020, live stream) highlights how the pandemic has enabled us to realize the creative power of social groups in improvising, solving, forging new rituals, simplifying, adapting, in short, building alternative scenarios which encourage religious creativity. In essence, it corresponds to the idea of devotional resistance by the creative movement of faith.

The organization of the institutional websites of religious sanctuaries, regardless of manifestations of faith, has broken away from dogmas and institutional interests regarding the symbolic traditions involved in ritualistic practices, many of which are centered on the social ties developed in-site with the use of the body.

We may cite, for example, baptism in the Catholic Church, and marriage, both sacraments that require in-site ritualistic and symbolic embodiments, and that have not yet found virtual substitutes during the pandemic (will they ever?).

The present paper gathers information from various locations in the nine Northeastern states. It is possible to consider that the views here depicted link three simultaneous dimensions, which will later be discussed in the perspective of the challenges to the future of religious tourism in pandemic conditions:

1) The public health impacts of the quarantine created restrictions, but caused forms of devotional resistance to emerge;

2) Online/offline celebration broadcasts opened space for new patterns of participation in individual and collective rites;

3) In the selected sample, organizations did not confront the local/regional public policy guidelines, which facilitates future dividend to religious tourism, in 
other socio-economic investment niches.

\subsection{Penedo (AL): Feast of Our Good Lord Jesus of the Seafaring}

The Feast of Our Good Lord Jesus of the Seafaring (Penedo) is one of the most representative religious festivities in Alagoas. In 2021, it reached the 137th edition, with the theme: Com Bom Jesus dos Navegantes, queremos proclamar o reino de Deus à toda criatura [With Our Good Lord Jesus of the Seafaring, we wish to preach the Kingdom of God to every creature]. The present study has searched the official Penedo City Hall social media (Instagram, Facebook and Youtube ${ }^{2}$ ), looking for the main measures adopted in the organization of the event in order to minimize of spread of coronavirus.

The slogan Ter fé sem aglomerar no Bomjé [Faith without agglomerate during the Feast] appears in one of the first posters circulated by the Penedo City Hall, in which mention is made of the changes imposed on the feast due to the world health crisis. Additionally, posts made before and during the celebration, which took place from 07 to 10 January 2021, indicate that both the Penedo City Hall and Diocese broadcast the entire event live in their respective social media. News of the event also informed the religious schedule, which differs from previous years, when secular side-events, with various artists of national renown, were among the main attractions for the public. The traditional format of the celebrations included a vast secular and religious schedule, culminating on the second Sunday of January, with land and river processions.

The procession originates in the very devotion to Bom Jesus [Our Good Lord Jesus], who is, in the popular imagination, strictly linked to fisherman. Tradition has it that two fishermen, upon finding themselves in danger in the waters of the São Francisco River, with imminent risk of death, would have vowed that, if saved, they would carry out a procession in honor of the protector of those waters, Bom Jesus (Britto, 2010; Torquato, 2018).

In 2021, with the pandemic-induced adaptations, there was no land procession, which was replaced by a motorcade with the image of Bom Jesus paraded in an open-sided car. This is very significant: in Penedo, the organization of processions (especially on land) mirrors power relations between those who hold economic and political capital: Guimarães reports that, in the houses of the most noble citizens, there were stations, so to say, where the procession stopped for an instant so the image was venerated by the noble families along the altars mounted on the route (Guimarães, 2014: p. 24). The motorcade set a milestone: for the first time, the image of Bom Jesus was not restricted to the historic center of the city, going to the upper part of the municipality.

The river procession, the heart of the festival, required several restrictions, limiting the numbers of vessels occupied every year by local devotees, pilgrims, etc. The musical band that usually accompanies the river procession was also absent. Access to the ferry carrying the image of Bom Jesus had to be done in

${ }^{2}$ The Penedo City Hall social media are the following: Facebook: @PrefeituraPenedo; Instagram: @prefeituradepenedo; YouTube: @PrefeituradePenedo. 
advance, and only for people accredited by the Diocese of Penedo (Vinícius, 2021c, onlnie). The rite of the peixamento, when fry are inserted in specific points of the São Francisco River, and which takes place on the same day of the processions, in partnership with Companhia de Desenvolvimento dos Vales do São Francisco e do Parnaíba (CODEVASF), was also absent from the 2021 edition. In 2020, for example, during the 136th edition, 50,000 curimatã-pacu (Prochilodus argenteus) fry were let into the river (Vinícius, 2021d, online).

Public administration and the local diocese also implemented other measures, with the support of several municipal secretariats: all masses were celebrated in an open structure set in the so-called Praça da Fé, with tents and seats respecting the appropriate distance to prevent the spread of coronavirus (Vinícius, 2021b, online).

Many different channels broadcast the events; City Hall publications contained guidelines, in an awareness campaign, advising people to follow all the evens from their homes. Nevertheless, when analyzing the videos posted on social media, especially on YouTube, it is noticeable that a number of believers preferred to attend the event, despite the risks. Religious experience in a traditional celebration, without the physical presence in the liturgical rites, does not seem to have the same strength. This edition, during the pandemic, opens the possibility for the increasingly hybrid use of digital social media and in-site liturgical rites. In addition to other, more punctual changes, the celebration of outdoor masses in Penedo seems to have met with approval, so much so that participants proposed that, in the coming years, outdoor masses be maintained, regardless of the pandemic (Vinícius, 2021a, online).

\subsection{Santa Cruz Dos Milagres (PI): Sanctuary Feast Triad; Oeiras (PI): Feast of Our Good Lord Jesus of the Steps of the Cross}

In Piauí it was possible to observe, already in March 2020, the first measures to contain the advance of the pandemic, following the regional and international recommendations of social isolation. Celebrations centered on popular Catholicism, such as its patron saint feasts, pilgrimages, ex-vows offerings, and other practices were affected by social distancing measures.

In order to understand these changes, we selected two representative examples of religious tourism in Piauí: 1) the city of Santa Cruz dos Milagres, home to the state's largest Catholic sanctuary; 2) the historic city of Oeiras, first capital of Piauí, with its rich heritage and expressive religious manifestations, such as Procissão do Bom Jesus dos Passos [Procession of Our Good Lord Jesus of the Steps of the Cross], Procissão do Fogaréu [Procession of Torches], and Feast of Whit Sunday.

Santa Cruz dos Milagres is located at approximately $180 \mathrm{~km}$ from the capital, Teresina; due to the pandemic, the festive triad associated with its recently expanded shrine (Silva, 2019), Feast of the Invention of the Holy Cross (May), Exaltation of the Holy Cross (September) and Encounter of the Saint (November), 
which are main celebrations of the liturgical calendar, was held without the presence of devotees in 2020. With the closure of the sanctuary and the changes in these feasts, the city was directly impacted, as they are an important source of income and revenue.

In periods of total closure, celebrations took place only with priests and liturgical staff. The economic impact was frightening, as the city's main economic activities are agriculture, small trade and public work, which is particularly active during the above-mentioned feasts. Thus, religious article merchants and workers assisting believers were the most affected so far.

With regard to the measures adopted by the Santa Cruz dos Milagres Parish, investment in religious market was already notorious, with the creation of websites, social media and printed newsletters sent to parishioner's houses, in order to spread news of the Sanctuary's activities, and engage parishioners. Despite the pandemic, the Parish sought to expand virtual contact with believers, by means of live broadcasts, Instagram TV channels, Portal Da Misericórdia [Mercy Web Portal], and especially the creation of a YouTube channel in April 2020, which expanded digital broadcast of celebrations.

Pilgrimage and evangelization were affected, as revenues, collected by means of letters sent to the parishioners, dwindled considerably; these donations are spontaneous, and contribute to cover the Parish's expenses, and even maintain the work positions it generates.

The city of Oeiras, located at $227 \mathrm{~km}$ from the state capital, Teresina, is an important historical city. With the pandemic, in 2020, the traditional Holy Week, held for approximately 180 to 200 years, according to remote documentary reports, and to a historian from Oeiras ${ }^{3}$, it was the first time that Holy Week was not celebrated in the city.

The first lockdown decrees in 2020 were issued a little more than a month before Holy Week and Feast of Our Good Lord Jesus of the Steps of the Cross (Pinheiro, Carvalho, \& Santos, 2020), a Portuguese-style via-sacra that runs through the historic center of the city, with purple-clad believers carrying ex-vows, keeping their vows and doing penances, held in the week before Holy Week.

At that frightening, tense and unknown moment for the devotees and for the Parish, it was only possible to watch the digital broadcast of the celebration. Some pilgrims still managed to follow the procession, but without crowds. The centenary chapels of the procession remained open and decorated, however, without visitation.

With a new wave of the pandemic in 2021, religious activities are still to follow protocols, decrees and regulations regarding COVID-19 prevention measures. Festive calendars do not hold the same expectations as before the pandemic, leading to uncertainty in the holding of traditional religious events.

${ }^{3}$ Virtual interview granted by Francisco de Assis Rocha Carvalho Júnior, historian, writer and professor from Oeiras, served as a member of the Instituto Histórico de Oeiras [Oeiras Historical Institute]. 


\subsection{Santa Cruz (RN): Feast of St. Rita of Cascia; Caicó (RN): Feasts of St. Anne of Caicó}

The investigation was based on the survey and analysis of the sites published on social media by the Archdiocese, Dioceses and parishes of the state of Rio Grande do Norte, as well as by lay people, organizers and promoters of the events. The media have modified the traditional forms of participation, through the use of digital technologies that allow believers to access the time of the festivities (Aguiar, 2014). By means of virtual interaction, they become generators and propagators of beliefs, by their testimonies and posts, keeping alive the "flame of faith".

Following technological evolution and the ensuing cultural and social changes, the Catholic Church has gradually invested on ICT: websites, blogs, YouTube channels, Instagram profiles, etc., that enable new forms of devotion, participation and interaction with the sacred.

Two of the most popular feasts were selected for study: 1) the Feast of St. Rita of Cascia, considered as a well-established route of religious tourism, which has chosen a different model of promotion, building one of the largest statues in the world; 2) the Feast of St. Anne of Caicó, one of the most traditional feasts of the region, having been registered by the National Historic and Artistic Heritage Institute (IPHAN) as intangible cultural heritage of the state of Rio Grande do Norte in 2010.

Celebrated in the city of Santa Cruz on May 22, the Feast of St. Rita of Cascia was broadcast on Facebook and Youtube by the Parish of St. Rita of Cascia. Believers were able to watch the novena-book masses, rosary prayers, the Coronation Mass and the procession of St. Rita of Cascia's image, with the participation of the cars of the Communication Pastoral (PASCOM), which carried the image, and Ministério de Música. As this is a pivotal and highly moving moment, some devotees, mostly residents of the city, insisted on participating in the procession, wearing masks and keeping distance.

The novelty was that, during the three days of the feast, the $56 \mathrm{~m}$ high statue, at the top of the sanctuary, was wearing a protective mask, with the colors of the flag of the city (Collet, 2020, online). This was part an awareness campaign by the City Hall, which emphasized the importance of wearing masks, by publishing photos of the masked statue on social media. According to Fr Vicente Fernandes, the purpose was to show St Rita spreading her message of understanding and peace, as well as self-care and concern for others. This year, the Tributo festivo em honra a Santa Rita de Cássia [Festive Tribute in Honor of Santa Rita of Cascia] was streamed live, reaching over 28,000 views by March 2021 (Paróquia De Santa Rita, 2020).

The annual feast of St. Anne in the city of Caicó, is celebrated on the last Sunday of July, and attracts thousands of devotees, family members, friends from Seridó potiguar and other Brazilian regions. In 2020, the feast was celebrated from July 26 to August 2, with live radio, TV and Internet broadcasts of masses 
and novenas, in addition to retransmission by the Diocese's radio stations. Reinventing the sociocultural rituals, there were virtual visitations of the image of St Anne to families, social app auctions, feijoada drive-through with previous purchase, and social media lives with local artists. The solemn 10 am mass was celebrated by Don Antonio Carlos Cruz Santos, Bishop of the Diocese of Caicó; there was also the closing $5 \mathrm{pm}$ mass and decent of the flag with the stamp of the patroness.

One of the highlights was the Fórum Festa de Sant'Ana de Caicó: Patrimônio Cultural do Brasil [Forum Feast of St Anne of Caicó: cultural heritage of Brazil], on July 28 and 29, with an online broadcast that brought together researchers, parish priests, politicians and members of the local community, to reflect on the development of Caicó and the Seridó region, based on discussions on the maintenance of the patroness' celebration, veneration and feasts. The YouTube channel Forum Festa de Sant ana displays seven thematic videos, with 150 subscribers; views range from 32 to 739 .

In their homilies, the celebrants emphasized: the importance of the mandatory use of masks to contain the spread of COVID-19, prayers invoking the intercession of the saints for families affected, a plea for civil authorities to conduct a more effective and humane policy, and the financial support of religious and social activities of the parish through tithes; this may be illustrated by the QR Code for bank transfers and the appeal that believer do not lose faith and hope amid the pandemic crisis. There are also chat rooms where believers express thanks, renew vows made to patron sanits and congratulate the organizers of the feast. The Solemn Mass was streamed live, with 13,000 views (Diocese De Caicó \& Paróquia De Sant'ana de Caicó, 2020).

Considered by the Parish as the feast of the patrons of the state of Rio Grande do Norte, in reference to the martyrdom that occurred 375 years ago in the state, the martyrs, André de Soveral, Ambrósio Francisco Ferro and Mateus Moreira, were canonized by Pope Francis on October 15, 2017. Celebration dates vary according to historical accounts: July 16, in Engenho Cunhaú, in the city of Canguaretama; October 3, in the community of Uruaçu, in São Gonçalo do Amarante, place with the highest flow of pilgrims, where the Sanctuary of Martyrs is located. In the neighborhood of Nazaré (Natal), where there is also a celebration, the Parish has announced on its website permission to attend the masses, so long as reservations are made in advance and regulations are met. People over 60, with co-morbidities or COVID-19 symptoms were barred from attending.

In 2020, exceptionally, the festivities took place virtually. The Archdiocese of Natal, responsible for the religious activities of the city, used social networks and digital media to disseminate and invite believers to participate in the rituals of celebration broadcast on YouTube and official church websites. During the novena period, September 23 to October 3, two masses were celebrated daily. On October 3 , in addition to the morning mass, there was the solemn closing $7 \mathrm{pm}$ mass, presided by Metropolitan Archbishop Jaime Vieira Rocha. 
In Cunhaú, in the city of Canguaretama, news of the celebrations followed the same dynamic, transmitted daily Parish of Canguaretama's website, Facebook page, TV station Rainha dos Mártires and on YouTube. The main piece advertising the celebration was the documentary on the history of the martyrs, with over 15,000 views (Arquidiocese De Natal, 2016, online).

\section{4. (SE): Feast of Our Good Lord Jesus of the Steps of the Cross}

In the city of São Cristóvão, from March 6 to 8, 2020, there occurred the traditional Feast of Our Good Lord Jesus of the Steps of the Cross, with three processions (Aragão \& Menezes, 2019): 1) on Friday, a procession from St Jude Thaddaeus Church (in the neighborhood of América, Aracaju) to Our Lord of the Steps of the Cross Church, in the historial center of São Cristóvão; 2) on Saturday, Procissão da Penitênica [Procession of Penance]; 3) on Sunday, Procissão do Encontro [Procession of Encounter]. According to the Archdiocese of Aracaju, the celebration, which has been taking place for more than a century, always on the second weekend of Lent, annually brings together approximately 80,000 people. The 2020 celebration edition was not affected by preventive measures.

In the case of the São Cristóvão Feast of Our Good Lord Jesus of the Steps of the Cross, stricter isolation rules were applied only in 2021. The historic center of São Cristóvão was isolated, as the three main accesses to the city, BR-101, João Bebe Água Highway and Zezinho Da Everest Highway, were blocked. Believers were unable to follow the aforementioned Friday procession, which took place on February 26. Throughout the weekend, access routes to the historic center remained blocked, and churches closed. As an alternative mitigating the impossibility of physical attendance and the absence of pilgrims, masses and processions were streamed live on the Our Lady of Victory Church YouTube channel ${ }^{4}$.

\subsection{Canindé (CE): Feasts of the Sanctuary of St Francis of the Wounds; Juazeiro Do Norte (CE): Feasts of the Juazeiro Do Norte Sanctuary}

In the state of Ceará, the Catholic Church follows the recommendations issued by the Episcopal Conference of Brazil (CNBB). These are sector-specific guidelines, and have been issued more systematically as of April 2020. An opportune social and pastoral example, which also applies to the sanctuaries here under study, are the instructions of the Comissão Episcopal Pastoral da Ação Sócio Transformadora das Pastorais Sociais da CNBB, Regional Nordeste I [CNBB's Episcopal and Pastoral Committee of Social Transformative Action, 1st Northeast Division]. The text highlights regulations concerning the COVID-19 pandemic and the problems in the prison system linked thereto (Cnbbne, 2020, online). The idea is to show the various degrees of expression of such regulations in how celebrations are conducted in three major Sanctuaries in the state of @ensvitoria. 
Ceará: Canindé, Juazeiro do Norte, and Tabuleiro do Norte (Olho D’água da Bica District).

Among other measures implemented by the Metropolitan Archdiocese (region of Fortaleza and neighboring cities), we may cite: the restriction of management activities, the suspension of the Feast of St Joseph, the cancellation of the XII Caminhada Penitencial [12ht Penitential Walk], the launching of the campaign: Tempos de Esperança e Solidariedade [Times of Hope and Solidarity], and the cancellation of the Caminhada com Maria [Walk with Mary] on August, 15, which event amasses thousands of participants in honor of the city of Fortaleza's patroness, Our Lady of the Assumption (Silva \& Oliveira, 2013). These instructions would reflect on the most traditional religious and processional feast of the archdiocese, at Sanctuary of St Francis of the Wounds, $120 \mathrm{~km}$ from Fortaleza.

The city of Canindé is under the jurisdiction of the Metropolitan Archdiocese of Fortaleza. The sanctuary has received various titles such as: "Sanctuary of the Backlands", "Sanctuary of the Northeast", "Northeastern Mecca", "Biggest Franciscan Sanctuary in the Americas", "Second Biggest Franciscan Sanctuary in the World" and "Metropolis Sanctuary".

The media communication practices of St Francis of the Wounds (Canindé) predate the coronavirus pandemic. The media of the administration of the Franciscan Campaign of Benefactors include: São Francisco Radio Station (AM 1.240 kHz), Santa Clara FM Station (106.3 MHz), Núcleo de Televisão do Santuário (NTS) [Sanctuary Television Network], Revista do Santuário [Sanctuary Magazine], Pastoral de Comunicação (PASCOM) [Communication Pastoral], Paz e Bem Communication System (which congregates municipal radios in festive times) and the Sanctuary's Facebook page.

Coronavirus' effects make evident the economic, fiscal, political, financial and sociocultural vulnerabilities of various different spheres. Decisions during a pandemic have proven to be the most difficult ones to make. In Canindé, 2020 will be marked as the "year of cancellations". The following celebrations were suspended: Easter celebrations, Marian Feast, Feast of St Anthony of Lisbon, Feast of Our Lady of Sorrows, Feast of St Clare and Feast of St Francis of the Wounds (the largest).

With regard to the media experiences imposed by social distancing, we note that the celebrations in honor of Our Lady of Sorrows, affectionately called "the mother of Sorrows", took place without public, only with liturgical participation. Both novenas and celebrations were broadcast on Youtube (NTS), the Sanctuary's Facebook page, and by radios stations (AM $1.240 \mathrm{kHz}$ and FM 106.3 MHz).

Digital broadcasts used the QR Code for donations; on YouTube, there were messages of healing and thanks. In the cafeteria, the novelty was the offer of delivery services and drive thru system. Clothes were displayed at an online thrift shop, and could be purchased by WhatsApp message. In addition, it was possible to make donations in the parish's office at extended hours; there was also a charity raffle. 
Understanding the potential of the media to spread messages and strengthen bonds, digital resources were used to guide parishioners, pilgrims, and St Francis devotees, regarding the gradual resumption of activities and possible changes due to state decrees. Measures adopted almost always include: social distancing with numbered seats; using hand sanitizers prior to entering temples; mandatory use of masks during the entire celebration; agglomeration-avoiding conducts of all sorts.

In addition to the documents issued, there were previously scheduled celebrations and reduced public. The visitation of churches during the celebration of the Feast of St Francis of the Wounds followed these restrictions. The mediation and mediatization of lives favored the 2020 celebration. At that time, the media strategy of adapting altars in the homes of believers showed: the official opening, the virtual raising of the flag of St. Francis, via sacra ceremonial; mass; novena and the show Momento da Festa. The latter was a news program and documentary of the celebration, and had to adapt to the Internet. The following hashtags were used: \#festejeemcasa [celebrate at home]; \#romariaemcasa [procession at home] and \#altardeSãoFranciscoemcasa [altar of St. Francis at home].

On the other hand, the pandemic prevented numerous collective events, cycle and bike intermunicipal pilgrimages, horseback riding, pilgrimages on foot and processions. Nevertheless, media devices allowed for some sort of reconnection, albeit not the desired one. This connection represents, in the previous understanding, an admirable step towards the transformation of relations between the Catholic Church and the media.

In the Diocese of Crato, in the south of the state of Ceará, the reconnection pervades more diverse mechanisms rooted in the cultural uniqueness of Juazeiro do Norte. The situation is a little more complex here, as the saint to be visited hasn't been canonized. In this sense, the church holds noticeably less power over pilgrimage practices. More recently, with the Mother Church under new management, Fr Cícero is becoming institutionally more accepted within the church. Such power struggles influence which authorities pilgrims will acknowledge on how practices are to be conducted. How have devotees, anxiously anticipating the arrival at the pilgrimage city, the touching of sacred objects, and rekindling their faith by means of sacred rituals, handled such drastic changes in devotion during the pandemic?

The devotees were directed by the rulers and religious leaders to stay at home. Traditional pilgrimages were canceled, and visitation to sacred places forbidden. The pandemic has strongly impacted Juazeiro do Norte, one of the largest pilgrimage centers in the country. It receives approximately two million people every year, and has been badly affected. In the city of massive pilgrimages, of crowds, there are still more punctual visits of groups and families, but far from what usually took place in the months of July, September, November and February, when the main streets were overcrowded and chaotic. Virtual visits now take the place of what was once affection, presence and gathering, imposing another type of chaos to the city-sanctuary. 
In the month closing the first year of the pandemic, Brazil continues to deal with despair, uncertainty, fear and social distancing measures. Fr Paulo César, secretary of Tourism and Pilgrimage of Juazeiro do Norte, recorded a nostalgic video commenting on the virtual Candeias Pilgrimage that took place in late January and early February. He says: "We must reflect on the pilgrimages, on coming to experience the pilgrimages in Juazeiro do Norte; we cannot allow the virus to spread to and fro, contaminating the people we love the most ... The Feast of Our Lady of Candeias will happen virtually" (Prefeitura Municipal De Juazeiro Do Norte, 2021, online).

The Basilica Minor of our Lady of Sorrow's social media broadcast the schedule of the Pilgrimage of Our Lady of Candeias. The masses were the only celebrations to admit public, at only 50\% church occupancy and mandatory reservation prior to attendance. The long-awaited and dear Procissão das Luzes [Procession of Lights] did not take place.

The pains to ensure a virtual pilgrimage and the intense schedule (similar to that which would have taken place before the pandemic) notwithstanding, some pilgrims still went to visit Fr Cícero's blessed grounds. The ecclesiastical guidelines, however, reiterate that all efforts are to minimize the high risk of contamination, which does not allow for the welcoming of a devotee in need, coming from afar, as was the case of a group of cyclists who arrived a little before Romaria da Esperança [Pilgrimage of Hope] (All Souls Day), and opened the Mother Church so they could pray and give thanks. The parish states that it has followed all sanitary protocols, but, as it is its duty to welcome those who come, it feels the need for sanitary barriers at the entrance of the city, so as to prevent situations like this, caused by people disrespecting social distancing.

\subsection{João Pessoa (PB): Penha Pilgrimage}

The centenary Maritime Procession of St Peter Fisherman, when fishermen carrying the image of St Peter in boats go from Penha Beach to Tambaú Beach (Baez \& Sampaio, 2019), is a relevant Catholic celebration in the state of Paraíba. The feast of Iemanjá, merged into the Catholic calendar, that has been taking place for more than half a century on December 8, the same day as the Celebration of Our Lady of Conception, which in João Pessoa is organized by the Umbanda and Candomblé centers.

It is interesting to note that these religious traditions in the capital city and the Metropolitan Region, specifically on the north and south coasts, are linked by their relation to the sea: starting with the Penha Sanctuary, whose chapel was built in 1764 on a hill facing the sea, by a castaway who dedicated his salvation to Our Lady. This annual pilgrimage would have seen its 257th edition in 2020. It is a $14 \mathrm{~km}$ walking route from the Church of Our Lady of Lourdes, on the center of the city, to the Sanctuary of Our Lady of Penha, on Penha Beach. The feast of Iemanjá, a sea deity, takes place on the waterfront of João Pessoa and Cabedelo; religious leaders and their filhos-de-santo travel to the beaches in chartered buses from neighboring locations, and, amid ritual performances, make offerings of 
flowers, perfumes and drinks taken by boat to the sea (Ruiz, 2016).

One last stop should be included in this rosário de romarias do mar [Rosary of sea pilgrimages] in João Pessoa and neighboring cities: the recently built charismatic shrine maintained by a religious organization called Servos de Maria do Coração de Jesus [Servants of Mary of the Heart of Jesus]. It is located in the city of Conde, on the southern coast of Paraiba, and is part of the state's coastal tourist route. This sanctuary was erected in the rural area, with a church and overnight accommodation buildings; it is what best represents religious tourism in the Metropolitan Region of João Pessoa, as it attracts pilgrims/tourists who come to see the sanctuary from several cities in the region all year round, assisted by tourist agencies. Tourists/pilgrims use the forum to make spiritual remarks, and also to comment on the reasonably priced food offered. The religious activities of the sanctuary community are either regular, such as masses, or happen sporadically, such as retreats, with the presence of young people, song and dance; part of them wears blue habits, and alleged aspirants wear long skirt and T-shirts.

These pilgrimages happened uninterruptedly until 2020, when, due to the pandemic, they were suspended by determination of the state government, complied with by the religious authorities of the different religious institutions, such as the Archdiocese of João Pessoa, parishes of St Peter Fisherman, Penha Sanctuary, and, representing religions of African matrix, Federação dos Cultos Afro-Brasileiros da Paraíba [Federation of African-Brazilian Religions of the State of Paraíba] (FCAB-PB). Measures promoting social distancing and preventing agglomerations limited these activities; there were initiatives to keep the devotional practices while restricting as much as possible the number of participants.

The Penha Pilgrimage takes place on the fourth Sunday of November; in 2020, due to the COVID-19 pandemic, the Archdiocese of Paraíba postponed it to December 12, and replaced it with a motorcade, with no cortege escorting the image. The masses throughout the day were made in accordance to safety protocols, with less than half of the usual occupancy: 250 out of 550 people. The sanctuary's social networks broadcast the celebrations; both the church and the pilgrimage feature in tourism websites as attractions; the seaside view from the church is also mentioned.

Romaria da Guia [Guia Pilgrimage] takes place on October 12, and was canceled in 2020 by the Parish of Lucena. The Guia Sanctuary, under the administration of the Carmelite Order, began to receive pilgrims to keep their vows before the image of Our Lady of Guia, following security protocols. With regard to the Maritime Procession of St. Peter Fisherman, no news was found about its occurrence, as there was no record of it having happened.

The Feast of Iemanjá was canceled, according to a note published by FCAB-PB in their social media; nevertheless, devotees and temples were guided to make their offerings to the sea deity taking all necessary precautions, and asked to pray and light candles for the health of all. 


\subsection{Candeias (BA): Feast of Our Lady of Candeias}

In the city of Candeias, in the Metropolitan Region of Salvador, approximately $50 \mathrm{~km}$ away from the capital of the state of Bahia, Our Lady of Candeias, the local patroness, is honored with an annual feast. The saint is represented in two different ways: in the temple and in the image of the altar, and rather immaterially in the municipal toponym. The urban landscape reinforces faith, with the temple setting itself apart in the visual field, depending on where one is and circulates in the urban area. This devotional practice is also strengthened in everyday discursive, when it is stated: "I live in Candeias".

In 2019, amid the increase of the pandemic, several religious holidays were postponed, reinvented and adapted to the new epidemiological reality. In the case of Candeias, an initial challenge was to try to contain the flow of visitors from other municipalities and the various forms of agglomeration. Devotees from the Metropolitan Region of Salvador, Recôncavo Baiano and other regions of the country visit Candeias, notably, in the first month of the year, when celebrations in honor of the patroness (masses, novenas, processions) take place. City Hall and ecclesiastical authorities took pains to avoid punctual or disperse agglomeration, as this religious celebration is strongly settled in specific points, such as the mother church, which carries strong symbolism for both locals and visitors.

Another important pilgrimage station in the vicinity of the mother church is the fountain; view as sacred, visitors wash their face and parts of their body in its waters, and bottle some of it to take home. Dubbed the "fountain of miracles", it is viewed by both locals and pilgrims as a highly symbolic place. The fountain is accessed by a causeway funneled in a slope. This route seems apt to increase the spread of the virus, for two reasons: as the path is funneled, there is close proximity among the walkers; also, there may be agglomeration in the points where water is accessed. Its waters carry a strong symbolic and religious value as a source of purification, healing and spiritual redemption. Despite the expressive symbolic relevance, visits to the fountain of miracles were suspended or limited.

Given the mobility restrictions, there arises the following question: how to prevent access to devotional places, such as shrines, in such a devastating context as that created by the pandemic? Sanitary measures are technically correct, however, such issues come to the fore when discussing the specificities of sanctuary cities.

At the beginning of the pandemic, in March 2020, masses were celebrated in a chapel inside the convent, by a priest with the help of two people, and broadcast on Instagram and Facebook. Subsequently, masses were once again celebrated within the mother church, with a larger liturgical and support group, to a limited congregation, following directives of social distancing by WHO and state and municipal government. Elderly people, considered as a risk group, were barred attendance, and passwords were distributed to participants. As slight improvements were observed in the pandemic, reservations were no longer required, and access to the temple was monitored, by measuring attendant's temperature and 
having them sanitize their hands with gel alcohol before entering, observing distance between them, limiting occupancy to $30 \%$, so as to avoid proximity that would conflict with the sanitary measures stated by the WHO. The large wooden pews were removed, as they would favor a agglomeration; plastic chairs were distributed, in accordance to maximum restricted occupancy and to state and municipal sanitary guidelines. Despite the severity of the pandemic, explained in various media, some did not accept imitations to the mother church occupancy, and insisted on entering.

Religious activities were almost entirely paralyzed at the Parish Our Lady of Candeias due to the intensification of the pandemic. In January 2021, novenas were made by phone appointment; participants were only allowed one night so that others could have a chance. To expand access, three Masses were celebrated during the day: $6 \mathrm{am}, 12: 15$ and 7:30 pm. On the day of the feast, five masses were celebrated. All these celebrations were held for city residents, since pilgrimages were prohibited.

As the traditional procession was suspended, the original image of Our Lady of Candeias was paraded in an open-sided car through some important streets of the city, being received by residents that decorated the fronts of the houses with religious ornaments to honor the saint in the late afternoon and early evening. It is important to note that this image rarely leaves the altar; only in very special occasions. In the procession, the sacred, embodied in the statue of the saint, is carried along the street and followed by dozens of believers. In the case of the open-sided car that carried the image of Our Lady of Candeias, people concentrated at the front of their houses on or sidewalks to see the sacred pass. To face the pandemic, stimulating the strengthening of faith, the Blessed Sacrament was paraded through the streets of the city.

In November, the pilgrimage of "faith and light" takes place, with the participation of parishes from several municipalities in the Metropolitan Region of Salvador, which make up the Diocese of Camaçari. On November 13, 2020, a virtual pilgrimage was made, with broadcast on the Diocese of Camaçari YouTube channel and on the Sanctuary of our Lady of Candeias Facebook page. An expressive number of people watched on social media.

\subsection{São José Do Ribamar (MA): Feast of St Joseph of Ribamar}

The city of São José de Ribamar stands out for the religiosity manifested through religious events, among which the celebration in honor of the St Joseph, which attracts every year an large number of visitors and tourists to thank graces achieved through faith (Azevedo, 2008: p. 11).

The sanctuary of São José de Ribamar is one of the main religious tourism points of the state of Maranhão. Before the pandemic, thousands of believers gathered in the streets of São José de Ribamar in the month of September, to celebrate their faith and belief in St Joseph.

Following the recommendations of the state government, the Archdiocese of São Luís, capital of Maranhão, issued a statement with guidelines to believers, 
suspending gatherings for ten days (from 05 to 14 March 2021), baptisms and marriages (Arquidiocese De São Luís, 2021, online).

The statement asks citizens "not to promote activities that motivate the flow of people in our communities"; it also advises "the elderly and people belonging to risk groups to follow the celebrations on social media"; this shows how the dynamics of the activities of the Sanctuary of St Joseph of Ribamar was reconfigured throughout the pandemic.

It is undeniable that the liturgical practices of religious institutions play a social role during the pandemic; its dynamic becomes all the more effective and takes up responsibilities beyond the realm of faith, such as the social and educational role religious discourse has in social processes. We know it is important to analyze religious feasts in their local context, showing aspects of its history and the constructive processes of a space mediated by a network of social agents that legitimize the event and the actions of both public and regional authorities (Alves, 2013: p. 25).

The COVID-19 pandemic has created a new demand for all groups: believers and pilgrims, politicians and public persons, and the local population. There were no processions and pilgrimages. Outside the Sanctuary, an altar structure was set up so masses with a larger attendance could be celebrated. Inside the church, pews were demarcated so as limit people's access. Gel alcohol was made available at the main entrance for hand sanitization; in addition, the use of masks was and still is mandatory (Fernandes, 2020, online).

The new dynamics of the Sanctuary of St Joseph of Ribamar may not be as new, since it was already interacting with believers, devotees and pilgrims through social media: its Facebook page exists since 2012; the Instagram profile was created in 2019. In his March 4 statement, Fr. Jadson Borba e Silva, head of the Archdiocese's Ação Evangelizadora Missionária [Missionary Evangelical Action], states: "given the current scenario of the pandemic, we are called to reiterate our commitment to the defense of life. As a church, we need to present ourselves consciously, open to the adaptation necessary to preserve the lives of all the faithful" (Arquidiocese De São Luís, 2021, online).

The Sanctuary of St Joseph of Ribamar does seem well adapted to the new media context during the pandemic; even before the pandemic, it was posting approximately 30 videos per year on its Facebook page; after measures of social distancing were issued, this number went up to 30 videos per month; daily masses began to be broadcast live on Facebook as of June 5, 2020. The importance of social media and a of virtual interaction environments should be highlighted, in their power to link and re-link (religare) the sanctuary and devotees, believers, pilgrims and other participants or visitors. In addition to the website of the Parish and Sanctuary of St Joseph of Ribamar ${ }^{5}$, where it is possible to learn its history in the municipality and its promotion to Archdiocese Sanctuary of St Joseph of Ribamar, under the leadership of Don Frei José Belisário da Silva, OFM, Archbishop of São Luís do Maranhão.

${ }^{5}$ Paróquia e Santuário de São José do Ribamar. https://www.santuarioderibamar.org/. 


\subsection{Brejo Da Madre De Deus (PE): Passion of Our Lord Jesus Christ of New Jerusalem; São Joaquim Do Monte (PE): Pilgrimage of Friar Damião; Serrita (PE): Cowherd Mass}

The analysis here presented is based on data collected from interviews, videos, podcasts, and information gathered on the websites, Facebook, Twitter, Instagram, and blogs belonging to the Aquidiocese of Olinda and Recife, to the State of Pernambuco's tourism agencies and departments, to the organizers of the events and to the actors involved in the religious tourism industry. Thus, they focused on the perceptions, recommendations, changes, cancellations and resignifications associated with religious tourism events in Pernambuco.

The first effects of the COVID-19 pandemic were evidenced with the promulgation of Decree No. 48,837 of March 23, 2020, which, among other restrictions, in its art. 3, prohibited public events of any nature. For the city of Brejo Da Madre de Deus, which hosts the Passion of our Lord Jesus Christ of New Jerusalem in the agreste [scrubland] of the state of Pernambuco, $180 \mathrm{Km}$ from the capital city Recife, it was a colossal social, economic and cultural shock: it was the first time the event was canceled in 53 years; having been initially postponed to 2021, it was once again postponed to 2022 as the pandemic continued.

For the city-theater that houses the largest open-air theater in the world, it was a sudden impact, as the entire event was organized, having been canceled only 15 days in advance in 2020. Before the pandemic, the event attracted approximately 250,000 people, with 70,000 watching the play.

The religious activity is part Pernambuco de todas as Paixóes [Pernambuco of All Passions], a brand with which the state government of Pernambuco promotes and funds Passion plays, portraying the physical mental and spiritual anguish faced by Jesus during his judgment and execution. The cancellation impacted the entire tourism chain, not only in economic-financial, but above all in cultural-religious terms.

The pandemic was faced resorting to ICT. This was the strategy used by organizers, archdioceses and managers to promote the religious tourism event, as a way to mitigate the effects of the pandemic in the state of Pernambuco. A religious event that aligns with this typology was the Pilgrimage of Friar Damião, in the city of São Joaquim do Monte, also in the agreste, which annually attracts approximately 150,000 believers. The organizers of the pilgrimage, held from September 3 to 6, 2020, called for remote participation, through social media, with celebrations inside the Mother Church and the chapel of São Sebastião being broadcast.

This is the first time the pilgrimage that began in 1993 in honor of a Capuchin friar whose beatification by the Catholic Church is underway, was done virtually. Here, it is necessary to highlight the concern of the organizers with the pandemic. At first, there was an inclination to allow visitation to Cruzeiro de Frei Damião, where a statue in his honor is on display, for prayers but with no crowds and procession; after a meeting with the Diocese of Caruaru, in Pernambuco, and other dioceses, it was opted for a strictly virtual celebration. The concern of 
the ecclesiastical authorities with the pandemic is visible, as well as the resources used to deal with the problem: "This will be a different pilgrimage, taking advantage of all the technology available today, so that the devotees are not deprived of their religious obligations", complemented Fr Izael. Thus, virtual participation was encouraged, thus safeguarding biosafety.

Another religious event organized as a digital edition was the Cowherd Mass, which attracts thousands of devotees and tourists to the city of Serrita, in the Pernambuco countryside. Celebrated since 1970, the tourist-religious event honors Vaqueiro Raimundo Jacó, cousin of the singer Luiz Gonzaga, murdered in 1954. This tribute to a cowherd reinstates the value of work and the idiosyncrasies and pains of cowherds in the northeast of Brazil; cowherds who attend the mass make offerings of their work attires and tools. The mass is celebrated on the third Sunday of July; during which time hotels and inns in the region of Serrita, Exu and Salgueiro record high occupancy rates.

To celebrate its fiftieth anniversary, the Catholic Church broadcast a mass on YouTube without disclosing the venue, to avoid crowds, and canceled the festivities, concerts and events correlated to the Cowboy Mass. All other previously planned events associated to the 50th anniversary were canceled, so as to avoid agglomeration, and in accordance to the diocese and state decree concerning the pandemic.

The Archdiocese of Olinda and Recife, together with public authorities, set protective measures, such as a $60 \%$ cut on sanctuary occupancy, restricted access to the image of our Lady of Conception, no devotee access to the velarium, mandatory use of protective masks and hand sanitizer in places of devotion, as well as social distancing. Masses were also broadcast on YouTube and social media.

These changes suggest the serious impact that COVID-19 has had on the religious terrorism in the state of Pernambuco, with events cancelled, restricted or realized partially or strictly online. For the tourist-hotel trade, the effects were more significant, due to the substantial reduction in the circulation of both devotees, pilgrims, believers and tourists.

\section{Final Remarks: In Search of Trends}

This overview drawn by REPETUR-NE, as a selection of cases representative of how northeastern religious tourism supply/demand has adapted in the last 12 months of coping (more or less rigidly) with the pandemic, did not include more specific observations on the states of Pernambuco and Bahia. This could be seen as a documental gap, had this reflection been intended as a complete and detailed tracking of information concerning all northeastern sanctuaries and celebrations with touristic visibility. On the contrary, the purpose was to investigate the confluence of emergency elements stemming from restrictive measures in relative harmony with tendencies of the exponential growth of media technologies in redesigning devotional cults and pilgrimages.

Therefore, in our final remarks (concluding the preliminary stage of our research with online tools), we can cite yet two Northeastern examples from the 
backlands of the states of Bahia and Pernambuco, which call attention due to their convergence. The diocesan cathedrals of Our Lady of the Angels (Petrolina, PE) and Our Lady of Grottos (Juazeiro, BA), on the left and right banks of the São Francisco River, form two ecclesial nuclei of novenas and festivities between August and September. Both represent historical Marian devotion in the more urban border between the two states; they are landmarks of this relative religious resistance with intense use of social media, scheduling, in the vicinities of their respective cities, motorcades, celebrations and in-site events in their limited 2020 edition. In addition to the rural traditions of the Velho Chico [Old Chico, as the São Francisco River is called] tourist offer, these dioceses communicated events, following sanitary protocols as indicated by news articles (e.g. G1 Petrolina, 2020, online; Rede GN, 2020, online) and on their Facebook pages ${ }^{6}$. To what extent does this reflect a more widespread situation in other inland (and coastal) regions of the nine northeastern states? This overview closes suggesting this question be tackled in more localized studies, which would receive a more in-depth treatment by research teams.

It should be remembered that Brazil identified the first cases of COVID-19 at the end of February 2020, when Europe already recorded hundreds of occurrences. Here, the Roman Apostolic Catholicism had to adapt to the new reality. In March 2020, CNBB issued the Roman Catholic Church's recommendations with a set of preventive measures, reinforcing the commitment of the Brazilian episcopate to maintain social distancing and collaborate with other institutions in the public and private sectors. When such measures are applied on a local scale, as in Juazeiro, Petrolina and other pilgrimage and feast centers, things may reinvent themselves taking a different turn. Conflicting and confusing interests of the federal government were mirrored in states and municipalities regarding the political and sanitary directions to be taken in the past 12 months.

There is no doubt that the adaptation and reinvention of virtual celebrations has allowed believers to join festivities from their homes, while generating and spreading beliefs, as we see in the testimonies regarding the production and access to information, as well as the availability and sharing of data. They promote constant renewal and reinvention of rituals, while facing the limitations of the new forms of sociability and handling criticism in favor of the continuity of tradition.

Devotion and faith are powerful tools for those facing the invisible monster of COVID-19 in such harsh times, marked by serialized shallow graves scattered through the country's cemeteries, multiplying images of fear and death (DURAND, 2019) deeply rooted in the human psyche. However, despite the fact that the most immediate means of salvation is found in the material realm of science, in the various vaccines being applied around the globe, it is in faith (religion), in their beliefs and devotion, that thousands of people are finding strength to overcome the adversities is generated by the pandemic.

Religion becomes all the more present in moments of consternation, when all

${ }^{6}$ The Dioceses' Facebook pages are the following: Our Lady of the Angels:

@paroquianossasenhorarainhadosanjos; Our Lady of Grottos: @ParoquiaSradasGrotas. 
are fearful of sickness, whether in the process of recreation and/or "reinvention of traditions" as a practice that consists of reconstructing, even forging the past to use it as an identifying mark or characteristic of a given place (Hobsbawm \& Ranger [eds], 1997), or, in the context of a pandemic, that changes the religious, political, social and economic organization of society, highlighting among them religious tourism.

On the other hand, one cannot deny the great changes that have taken place in relation to the celebrations of masses, novenas, rosaries and pilgrimages during the pandemic. In order to bypass what Oliveira calls an operational waste of faith-based organizations with their plurality of values that are threatened by the disruption of social bonds, which are a pivotal importance in times like this, especially concerning the large investment and logistics around religious feasts, new dynamics need to be developed: changes in the organization of the physical space of parishes and churches, suspension of shrine visitations, special celebrations with electronic means, either pre-recorded or live, construction of specific social networks to answer to local communities and/or visitors during festive times.

Thus, the time has come to associate this "panorama of mutations" (with continuities and discontinuities) to the dimensional challenges mentioned as tendencies for religious tourism during the pandemic, building a representation that better evidences certain hierarchical tendencies. In these terms, we wish to present a hypothesis comes from the limited diversity of the touristic reinventions gathered throughout this essay. One such way of formulating this hypothesis is the following: devotional resistance opens provisionally and reservedly a space for new patterns of online/off-line broadcast of cults and visitations. But in itself, such resistance does not significantly expand into new investment niches of religious tourism, as events are almost exclusively broadcast as internal events, far from other local demands.

Figure 1 attempts to graphically render and synthesize this hypothesis. As a closing remark, it is important to challenge future studies of northeastern religious tourism in the emergence of mass vaccination that, in 2021, points to overcoming the impact of the pandemic. The above hypothesis must undergo a rigorous check, with these advances, whether in state or local spheres, in order to provide a deeper understanding of elements here left unexplored.

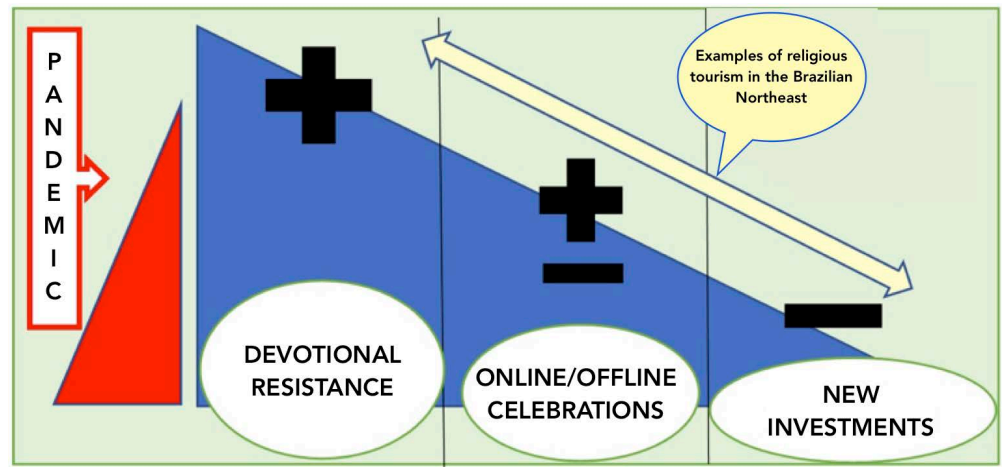

Figure 1. Hypothetical hierarchical tendencies Source: The authors (2021). 


\section{Acknowledgements}

The authors are grateful to the CAPES/FUNCAP Proc. 88887.165948/2018-00: Support for Scientific Cooperation Strategies of the Graduate Program in Geography: UFC for financing the costs of translation and editing of this study.

\section{Conflicts of Interest}

The authors declare no conflicts of interest regarding the publication of this paper.

\section{References}

Aguiar, C. E. S. (2014). A sacralidade digital: Religióes e religiosidade na época das redes. São Paulo: Annablume.

Alves, M. L. B. (2013). Turismo e religiosidade: Uma tentativa de diálogo. Revista Iberomericana de Turismo-RITUR, 3, 25-37. https://www.seer.ufal.br/index.php/ritur/article/view/980

Aragão, I., \& Menezes, H. (2019). A festa do Senhor dos Passos em São Cristóvão/SE, a partir das memórias de Dona Neném. Caderno de Pesquisa do CDHIS, 32, 191-203. https://doi.org/10.14393/cdhis.v32n2.2019.52165

Arquidiocese de Natal (2016). Série Mártires de Cunhaú e Uruaçu-Vídeo 1. Arquidiocese de Natal. 7m49s. https://www.youtube.com/watch?v=CC-XLPKPbuc

Arquidiocese de São Luís (2021). Orientações da Arquidiocese de São Luís para o atual cenário da pandemia. https://www.facebook.com/arquislma/posts/3652643368182789

Azevedo, A. P. M. (2008). São José de Ribamar, um santuário de fé no Maranhão (São Luís) Monograph. Federal University of Maranhão.

https://sigaa.ufma.br/sigaa/public/curso/documentos curso.jsf?lc=es ES\&lc=pt BR\&id $=85818$

Baez, G. C. O., \& Sampaio, D. S. (2019). Territórios “sagrados” da pesca artesanal em João Pessoa: Identidades e sacralização de espaços públicos na Festa de São Pedro Pescador. Rever-Revista de Estudos da Religião, 19, 219-234. https://doi.org/10.23925/1677-1222.2019vol19i3a13

Boni, R. B. D. (2020). Websurveys nos tempos de COVID-19. Cadernos de Saúde Pública, 36, Article ID: e00155820. https://doi.org/10.1590/0102-311X00155820

Britto, A. A. V. L. (2010). A Festa de Bom Jesus dos Navegantes em Propriá-SE: História de fé, espaço das relações sociais e laços culturais. Master's Thesis, Natal: Federal University of Rio Grande do Norte.

Camargo, H. P., Santos, R. J. D., \& Guterres, L. S. (2012). Antropologia no ciberespaço: buscando compreender as experiências de deslocamento humano. Rosa dos Ventos, 4, 575-586. http://www.ucs.br/etc/revistas/index.php/rosadosventos/article/view/1667

Canclini, N.G. (2006). Culturas Híbridas: Estratégias para entrar e sair da Modernidade. São Paulo: Edusp.

Carranza, B., Carvalho, I. C. D. M., \& Bandeira, O. (2020). Reacciones religiosas al COVID-19 en América Latina. Ciencias Sociales Y Religión/Ciências Sociais E Religião, 22, Article ID: e020036. https://doi.org/10.20396/csr.v22i00.14830

CNBBNE1 (Conferência Nacional dos Bispos do Brasil-Regional Nordeste 1) (2020). Sobre a pandemia da covid-19 no sistema carcerario cearense. Fortaleza: Conferência Nacional dos Bispos do Brasil-Regional Nordeste 1. 
http://www.cnbbne1.org.br/regional-nordeste-1-emiti-nota-sobre-a-pandemia-do-covi d-19-no-sistema-carcerario-cearense/

Collet, A. (2020). Estátua de Santa Rita ganha máscara para conscientizar o mundo sobre a COVID-19. Vatican News.

https://www.vaticannews.va/pt/igreja/news/2020-05/santa-rita-de-cassia-estatua-commascara-coronavirus-rn-brasil.html

Diocese de Caicó, Paróquia De Sant'ana de Caicó (2020). Missa Solene: Festa de Sant'Ana de Caicó-RN 2020. TV Kurtição. 2h06m.

https://www.youtube.com/watch?v=Vlf8gY4ipeQ

Durand, G. (2019). As estruturas antropológicas do imaginário. São Paulo: WMF.

Fernandes, F. (2020). Pandemia altera a programação do tradicional festejo de São José de Ribamar. Ma10.com.br https://www.ma10.com.br/2020/09/02/pandemia-altera-a-programacao-do-tradicional -festejo-de-sao-jose-de-ribamar/

G1 Petrolina (2020). Começa nesta quarta-feira (5) o novenário a Nossa Senhora Rainha dos Anjos em Petrolina, PE. Globo.com

https:/g1.globo.com/pe/petrolina-regiao/noticia/2020/08/05/comeca-hoje-o-novenario -a-nossa-senhora-rainha-dos-anjos-em-petrolina-pe.ghtml

Guimarães, E. V. C. (2014). Entre janelas e camarotes: o sagrado e o profano na festa do Bom Jesus dos Navegantes de Penedo/AL. Master's Thesis, São Cristovão: Federal University of Sergipe.

Hall, S. (2006). A identidade cultural na pós-modernidade. Rio de Janeiro: DP \& A Editora.

Hobsbawm, E., \& Ranger, T. (Eds.) (1997). A invenção das tradições. Rio de Janeiro: Paz e Terra.

Levy, P. (1999). Cibercultura. São Paulo: EDITORA 34.

Menezes, R., Machado, C., Pacheco, R., Toniol R., \& Novaes, R. (2020). Religiosidades na pandemia, nas redes e nas mídias. ISER Comunicação. $118 \mathrm{~m}$. https://www.youtube.com/watch?v=ekVPiox2Kac

Palhares, C. M. (2015). Turismo na Reinvenção da Imagem de Brasília, cidade criativa. Master's Thesis, Brasília: University of Brasília.

Paróquia de Santa Rita RN (2020). Tributo festivo em honra a Santa Rita de Cássia: Procissão de Santa Rita 2020. Paróquia de Santa Rita RN. 4h55m. https://www.youtube.com/watch?v=JSN4zb2p6QE

Pinheiro, A. D. P, Carvalho, R. D. C. M., \& Santos, F. S. F. D. (2020). Os inventários da Celebração de Bom Jesus dos Passos, Oeiras, Piauí, Brasil. Em Questão, Vol. 26, Edição Especial Dossiê Patrimônio e Culturas Tradicionais, 235-260. https://doi.org/10.19132/1808-5245260.235-260

Prefeitura Municipal de Juazeiro do Norte (2021). Mensagens aos romeiros sobre a Romaria de Candeias. Prefeitura Juazeiro do Norte. $2 \mathrm{~m} 16 \mathrm{~s}$. https://www.youtube.com/watch? $\mathrm{v}=\mathrm{jPWa}$ J JfBGIo\&t $=4 \mathrm{~s}$

RedeGN (2020). Carreata marcará abertura do Novenário de Nossa Senhora das Grotas, Padroeira de Juazeiro (BA), neste domingo (30). redeGN. https://www.redegn.com.br/index.php?sessao=noticia\&cod noticia $=136176$

Ruiz, M. (2016). Política e devoção na festa de nossa senhora da Conceição no Porto do Capim, João Pessoa (PB). Master's Thesis, João Pessoa: Federal University of Paraíba. https://repositorio.ufpb.br/jspui/bitstream/tede/8589/2/arquivototal.pdf

Sánchez, F. (2003). A reinvenção das cidades para um mercado mundial. Argos, Chapecó. 
Santos, V. L. P. D., \& Costa, C. J. D. S. A. (2015). A observação online como instrumento investigativo: Uma experiência utilizando fórum de discussão. Debates em Educação, 7, 56-77. https://doi.org/10.28998/2175-6600.2015v7n14p56

Senghor, É. (2020). Turismo religioso no evento covid-19. Desarrollo, Economía Y Sociedad, 9, 86-92. https://190.14.250.82/revistas/index.php/deyso/article/view/661/627

Silva, K. C. D. (2019). Nos passos do peregrino: Turismo e religiosidade em Santa CruZ dos Milagres (PI). Master's Thesis, Natal: Federal University of Rio Grande do Norte. https://repositorio.ufrn.br/handle/123456789/26860

Silva, L. R. T. D., \& Oliveira, C. D. M. D. (2013). A Conquista da Metrópole Profana: Uma análise da territorialidade religiosa como instrumento da patrimonialização imaterial em Fortaleza (CE). Revista Brasileira de Ecoturismo, 6, 81-92.

https://doi.org/10.34024/rbecotur.2013.v6.6121

https://periodicos.unifesp.br/index.php/ecoturismo/article/view/6121

Torquato Jr., E. (2018) "E Lá Vem Ele”: Uma Etnografia da Procissão do Senhor Bom Jesus dos Navegantes em Penedo/AL. Dissertação Master's Thessi, Maceió: Universidade Federal de Alagoas.

Vinícius, F. (2021a). Diocese e devotos aprovam Praça da Fé para celebrar Bom Jesus em Penedo. Prefeitura de Penedo.

https://penedo.al.gov.br/2021/01/11/diocese-e-devotos-aprovam-praca-da-fe-para-cele brar-bom-jesus-em-penedo/

Vinícius, F. (2021b). Louvor ao Bom Jesus dos Navegantes é transmitido, ao vivo, da Praça da Fé. Prefeitura de Penedo.

https://penedo.al.gov.br/2021/01/10/louvor-ao-bom-jesus-dos-navegantes-e-transmitid o-ao-vivo-da-praca-da-fel

Vinícius, F. (2021c). Pandemia interfere na programação de Bom Jesus dos Navegantes em Penedo. Prefeitura de Penedo.

https://penedo.al.gov.br/2021/01/10/pandemia-interfere-na-programacao-de-bom-jesu s-dos-navegantes-em-penedo- $2 /$

Vinícius, F. (2021d). Peixamento no Rio São Francisco não ocorrerá na Festa de Bom Jesus de Penedo. Prefeitura de Penedo.

https://penedo.al.gov.br/2021/01/10/peixamento-do-rio-sao-francisco-nao-ocorrera-na -festa-de-bom-jesus-de-penedo/ 